\title{
Sedative Action of Cholecystokinin Octapeptide on Behavioral Excitation by Thyrotropin Releasing Hormone and Methamphetamine in the Rat
}

\author{
Goro KatsuUra and Shinji IтоH \\ Shionogi Research Laboratories, Shionogi \& Co., Ltd., \\ Fukushima-ku, Osaka, 553 Japan
}

\begin{abstract}
Intracerebroventricular (i.c.v.) injection of C-terminal octapeptide of cholecystokinin (CCK-8) in rats prolonged pentobarbitaland ethanol-induced sleeping time, but non-sulfated CCK-8 (CCK-8-NS) had no effect and caerulein showed a tendency to prolong the pentobarbital narcosis. On the other hand, i.c.v. injection of thyrotropin releasing hormone (TRH) shortened the sleeping time and the effect of CCK-8 was apparently antagonized by combined administration of TRH. Spontaneous locomotor activity in the late morning and early afternoon was not affected by CCK-8, but it increased following i.c.v. injection of CCK-8-NS. Hyperactivity produced by TRH and methamphetamine was suppressed by i.c.v. injection of CCK-8, while CCK8-NS showed a tendency to enhance the methamphetamine-induced hyperactivity and caerulein had no effect. These results indicate that CCK-8 has a sedative action and antagonizes the behavioral excitation caused by TRH and methamphetamine, but that the effects of CCK-8NS and caerulein were rather the opposite of those of CCK-8. In an additional experiment the TRH-induced body shaking response was not affected by combined administration of CCK-8.

Key Words: cholecystokinin, thyrotropin-releasing hormone, sleeping time, locomotor activity.
\end{abstract}

Recently, it has been reported by ZETLER (1980a) that s.c. injection of caerulein and CCK-8 delays the onset and retards the development of toxic effects of several convulsants and increases the seizure threshold of i.v. injection of these drugs. ZETLER (1980b) also found that s.c. injection of caerulein and CCK-8 inhibited spontaneous rearing activity and prolonged hexobarbital sleeping time in mice. On the other hand, TRH has been shown to potentiate L-DOPAinduced excitation (PlotNikoff et al., 1972, 1974) and to shorten the sleeping time induced by barbiturates and other depressants (BREESE et al., 1975; BROWN and VALE, 1975; CotT et al., 1976) in rats and mice. Central behavioral excita-

Received for publication July 25, 1981

勝浦五郎, 伊藤眞次 
tion and a hyperthermic response to TRH were also reported in rabbits (CARINO et al., 1976). Such general excitation included an increase in locomotor activity (MANBerg et al., 1979). According to these literature data, CCK-8 is likely to antagonize the behavioral excitation induced by TRH and other central stimulants. The present study was carried out to ascertain this possibility, comparing the effects of CCK-8 with those of its related peptides.

\section{MATERIALS AND METHODS}

Male Wistar rats, weighing approximately $250 \mathrm{~g}$, were housed under constant conditions of $25^{\circ} \mathrm{C}$ and a $12 \mathrm{hr}$ light/dark cycle, with rat biscuits (Oriental Yeast Co.) and water provided ad libitum.

The method of i.c.v. injection has been described in detail in our previous paper (Ітон et al., 1979). In brief, a stainless steel guide cannula was fixed stereotaxically on the skull by dental cement, and the animals were allowed 5 days for recovery from the surgery. Thereafter, they became accustomed to insertion of an injection cannula into the left lateral ventricle for another 5 days.

In order to observe effects on the sleeping time, sodium pentobarbital (Pitman-Moore) in a dose of $50 \mathrm{mg} / \mathrm{kg}$ was injected i.p. at around 10:00 hr and 10 min later a $5 \mu 1$ sample of saline, CCK-8 (Squibb), CCK-8-NS (Peninsula Labs.), caerulein (Calbiochem) or TRH (Sigma) was injected i.c.v. in the doses shown in the following tables. Sleeping time was assessed by observing the time elapsed from the loss of the righting reflex to its recovery. In the case of ethanolinduced sleeping, $25 \%$ ethanol solution in a dose of $3.5 \mathrm{~g} / \mathrm{kg}$ was injected i.p. at around 10:00 hr, and $10 \mathrm{~min}$ later test samples were injected i.c.v. and the onset and duration of sleeping time were measured.

Locomotor activity of the rat was monitored using an Automex (Columbus Instruments) with one rat per cage. In the morning, after the rats were allowed $75 \mathrm{~min}$ to become accustomed to the cage, a $5 \mu \mathrm{l}$ sample of saline, CCK-8, CCK8-NS, or TRH was injected i.c.v. and activity was recorded every $10 \mathrm{~min}$ for 60 min. Methamphetamine (Dainippon Pharm. Co.) was injected s.c. in a dose of $0.15 \mathrm{mg} / \mathrm{kg}$ and $1 \mathrm{~min}$ later CCK-8, CCK-8-NS or caerulein was injected i.c.v. into the rats. Body shaking following i.c.v. injection of TRH and/or CCK-8 was also counted for $60 \mathrm{~min}$.

The data were analyzed by Student's $t$-test and significant differences between the means were calculated as $P$ values.

\section{RESULTS}

Pentobarbital-induced sleeping time

After i.p. injection of pentobarbital, CCK-8 in doses from 200 to $1,600 \mathrm{ng}$ was administered i.c.v. and sleeping time was measured. As shown in Table 1, 
Table 1. Effect of intracerebroventricular injection of CCK-8, its related peptides, and TRH on pentobarbital-induced narcosis.

\begin{tabular}{|c|c|c|c|c|c|}
\hline \multirow{2}{*}{ Treatment } & \multirow{2}{*}{$\begin{array}{c}\text { Dose } \\
\text { (ng) }\end{array}$} & \multirow{2}{*}{$\begin{array}{l}\text { No. of } \\
\text { rats }\end{array}$} & \multicolumn{2}{|c|}{$\begin{array}{c}\text { Sleeping time } \\
\text { min (mean } \pm \text { S.E.M.) }\end{array}$} & \multirow{2}{*}{$t$-Test } \\
\hline & & & Onset & Duration & \\
\hline Saline & & 11 & $3 \pm 0.2$ & $57 \pm 1.9$ & \\
\hline \multirow[t]{4}{*}{ CCK-8 } & 200 & 5 & $3 \pm 0.2$ & $56 \pm 2.7$ & N.S. \\
\hline & 400 & 11 & $3 \pm 0.1$ & $62 \pm 1.6$ & $P<0.05$ \\
\hline & 800 & 9 & $3 \pm 0.1$ & $65 \pm 2.4$ & $P<0.05$ \\
\hline & 1,600 & 9 & $3 \pm 0.1$ & $75 \pm 3.2$ & $P<0.001$ \\
\hline Saline & & 13 & $3 \pm 0.1$ & $56 \pm 2.4$ & \\
\hline \multirow[t]{3}{*}{ CCK-8-NS } & 400 & 9 & $3 \pm 0.2$ & $55 \pm 3.1$ & N.S. \\
\hline & 800 & 12 & $3 \pm 0.2$ & $63 \pm 2.8$ & N.S. \\
\hline & 1,600 & 10 & $3 \pm 0.1$ & $55 \pm 2.9$ & N.S. \\
\hline Saline & & 11 & $3 \pm 0.2$ & $53 \pm 2.6$ & \\
\hline \multirow[t]{4}{*}{ Caerulein } & 200 & 16 & $3 \pm 0.1$ & $54 \pm 1.3$ & N.S. \\
\hline & 400 & 7 & $3 \pm 0.1$ & $63 \pm 2.0$ & $P<0.05$ \\
\hline & 800 & 9 & $3 \pm 0.3$ & $61 \pm 2.3$ & $P<0.05$ \\
\hline & 1,600 & 8 & $3 \pm 0.2$ & $59 \pm 2.9$ & N.S. \\
\hline Saline & & 18 & $3 \pm 0.1$ & $55 \pm 1.5$ & \\
\hline \multirow[t]{5}{*}{ TRH } & 25 & 7 & $3 \pm 0.2$ & $50 \pm 2.1$ & N.S. \\
\hline & 50 & 14 & $3 \pm 0.2$ & $48 \pm 1.9$ & $P<0.01$ \\
\hline & 100 & 8 & $3 \pm 0.2$ & $46 \pm 1.6$ & $P<0.001$ \\
\hline & 200 & 12 & $3 \pm 0.1$ & $45 \pm 1.6$ & $P<0.001$ \\
\hline & 400 & 10 & $3 \pm 0.2$ & $41 \pm 2.9$ & $P<0.001$ \\
\hline CCK-8 & 1,600 & & & & $P<0.01$ vs. CCK-8 alone \\
\hline TRH & 200 & 7 & $3 \pm 0.2$ & $53 \pm 4.9$ & N.S. vs. TRH alone \\
\hline CCK-8 & 1,600 & 9 & 5 & $46+30$ & $P<0.001$ vs. CCK-8 alone \\
\hline TRH & 400 & 9 & $3 \pm 0.5$ & $40 \pm 3.0$ & N.S. vs. TRH alone \\
\hline
\end{tabular}

Each material was injected in a volume of $5 \mu 1$. N.S.: not significant.

after administration of CCK-8 in doses of more than $400 \mathrm{ng}$, the duration of sleep was prolonged significantly, this effect being dose-dependent. However, CCK-8-NS did not cause such prolongation of the sleeping time. TRH when injected i.c.v. in doses of more than $50 \mathrm{ng}$, shortened the sleeping time markedly. When 1,600 ng of CCK-8 was injected together with $200 \mathrm{ng}$ of TRH, the narcotic effect of CCK- 8 was diminished by TRH, the sleeping time after combined injection of $1,600 \mathrm{ng} \mathrm{CCK}-8$ and $400 \mathrm{ng}$ TRH being remarkably shorter than the time after CCK-8 alone.

\section{Ethanol-induced sleeping time}

Similar results were obtained in rats treated with ethanol (Table 2). In the control group, the duration of sleep increased by i.c.v. injection of CCK-8 in a dose of $1,600 \mathrm{ng}$, while TRH produced a marked reduction in the sleeping time. 
Table 2. Effect of intracerebroventricular injection of CCK-8 and TRH on ethanol-induced narcosis.

\begin{tabular}{|c|c|c|c|c|c|}
\hline \multirow{2}{*}{ Treatment } & \multirow{2}{*}{ Dose } & \multirow{2}{*}{$\begin{array}{l}\text { No. of } \\
\text { rats }\end{array}$} & \multicolumn{2}{|c|}{$\begin{array}{c}\text { Sleeping time } \\
\text { min (mean } \pm \text { S.E.M.) }\end{array}$} & \multirow{2}{*}{$t$-Test } \\
\hline & & & Onset & Duration & \\
\hline Saline & & 10 & $5 \pm 0.1$ & $58 \pm 3.8$ & \\
\hline \multirow[t]{4}{*}{ CCK-8 } & $200 \mathrm{ng}$ & 9 & $3 \pm 0.1$ & $64 \pm 4.9$ & N.S. vs. saline \\
\hline & 400 & 8 & $4 \pm 0.6$ & $60 \pm 6.3$ & N.S. \\
\hline & 800 & 12 & $4 \pm 0.2$ & $59 \pm 3.6$ & N.S. \\
\hline & 1,600 & 10 & $3 \pm 0.2$ & $71 \pm 4.9$ & $P<0.01$ \\
\hline \multirow[t]{4}{*}{ TRH } & $5 \mu \mathrm{g}$ & 6 & $3 \pm 0.2$ & $50 \pm 7.2$ & N.S. \\
\hline & 10 & 7 & $3 \pm 0.3$ & $44 \pm 4.3$ & $P<0.05$ \\
\hline & 20 & 9 & $4 \pm 0.9$ & $37 \pm 3.8$ & $P<0.001$ \\
\hline & 40 & 12 & $5 \pm 0.7$ & $39 \pm 5.1$ & $P<0.001$ \\
\hline $\begin{array}{l}\text { CCK-8 } \\
+ \\
\text { TRH }\end{array}$ & $\begin{array}{r}1,600 \mathrm{ng} \\
40 \mu \mathrm{g}\end{array}$ & 9 & $3 \pm 0.2$ & $47 \pm 2.3$ & $\begin{array}{l}P<0.001 \text { vs. CCK-8 alone } \\
\text { N.S. vs. TRH alone }\end{array}$ \\
\hline
\end{tabular}

Each material was injected in a volume of $5 \mu$. N.S.: not significant.

Table 3. Effect of intracerebroventricular injection of CCK-8 and CCK-8-NS on spontaneous locomotor activity and the effect of

CCK-8 on TRH-induced hyperactivity.

\begin{tabular}{|c|c|c|c|c|}
\hline Treatment & $\begin{array}{l}\text { Dose } \\
\text { (ng) }\end{array}$ & $\begin{array}{l}\text { No. of } \\
\text { rats }\end{array}$ & $\begin{array}{c}\text { Locomotor activity } \\
\text { Counts/hr } \\
\text { (mean } \pm \text { S.E.M.) }\end{array}$ & $t$-Test \\
\hline Saline & & 11 & $593 \pm 53$ & \\
\hline \multirow[t]{5}{*}{ CCK-8 } & 100 & 12 & $826 \pm 125$ & N.S. vs. saline \\
\hline & 200 & 12 & $689 \pm 60$ & N.S. \\
\hline & 400 & 9 & $648 \pm 67$ & N.S. \\
\hline & 800 & 9 & $524 \pm 98$ & N.S. \\
\hline & 1,600 & 9 & $502 \pm 79$ & N.S. \\
\hline Saline & & 9 & $518 \pm 94$ & \\
\hline \multirow[t]{3}{*}{ CCK-8-NS } & 400 & 7 & $474 \pm 119$ & N.S. vs. saline \\
\hline & 800 & 8 & $1,078 \pm 173$ & $P<0.05$ \\
\hline & 1,600 & 9 & $1,302 \pm 96$ & $P<0.001$ \\
\hline TRH & 100 & 12 & $1,700 \pm 159$ & \\
\hline TRH & 100 & & & \\
\hline+ & & 12 & $1,301 \pm 109$ & N.S. vs. TRH alone \\
\hline CCK-8 & 100 & & & \\
\hline$\underset{+}{\text { TRH }}$ & 100 & 12 & & $P<0 \quad 05$ \\
\hline CCK-8 & 200 & 12 & $1,164 \pm 113$ & $P<0.05$ \\
\hline TRH & 100 & & & \\
\hline$\stackrel{+}{\mathrm{CCK}-8}$ & 400 & 9 & $1,021 \pm 97$ & $P<0.01$ \\
\hline
\end{tabular}

Each material was injected in a volume of $5 \mu 1$. N.S.: not significant. 
When $40 \mu \mathrm{g}$ of TRH was administered together with $1,600 \mathrm{ng}$ of CCK-8, the sleeping time was significantly shorter than that after CCK-8 alone. However, it should be noted herewith that the dose of TRH needed to shorten the duration of ethanol-induced sleep was 50 to 100 times greater than the dose to shorten the pentobarbital-induced sleep.

\section{Spontaneous locomotor activity}

Locomotor activity of rats, as measured with an Automex between 11:00 and 14:00 hr, was not affected by i.c.v. injection of CCK-8 in doses from 100 to $1,600 \mathrm{ng}$ (Table 3). On the other hand, i.c.v. injection of CCK-8-NS produced an increase in the activity counts. TRH in a dose of $100 \mathrm{ng}$ produced a pronounced increase in the activity and the counts became nearly 3 -fold higher than those of the saline control. When TRH at this dose was injected simultaneously with CCK-8, the increase in locomotor activity was significantly suppressed. A similar result was also obtained in an experiment on methamphetamine-induced hyperactivity (Table 4). In this case, an almost 2-fold increase in the activity counts was induced by methamphetamine. This hyperactivity was greatly reduced by CCK-8 in doses of more than $400 \mathrm{ng}$.

Differing from the effects of this CCK-8, CCK-8-NS in doses of 400 and $800 \mathrm{ng}$ did not cause any decrease in the activity counts in methamphetaminetreated rats. When the latter peptide was injected i.c.v. in relatively large amounts up to $1,600 \mathrm{ng}$, the activity increased significantly. Caerulein was found to be ineffective in producing any change in methamphetamine-induced hyperactivity.

Table 4. Effect of intracerebroventricular injection of CCK-8 and its related peptides on methamphetamine-induced hyperactivity.

\begin{tabular}{lrrcl}
\hline \multicolumn{1}{c}{ Treatment } & $\begin{array}{c}\text { Dose } \\
\text { (ng) }\end{array}$ & $\begin{array}{c}\text { No. of } \\
\text { rats }\end{array}$ & $\begin{array}{c}\text { Locomotor activity } \\
\text { Counts/hr (mean } \pm \text { S.E.M.) }\end{array}$ & $t$-Test \\
\hline Saline & & 13 & $1,396 \pm 136$ & \\
CCK-8 & 200 & 7 & $1,149 \pm 136$ & N.S. vs. saline \\
& 400 & 9 & $873 \pm 148$ & $P<0.05$ \\
& 800 & 9 & $804 \pm 127$ & $P<0.01$ \\
Saline & & 13 & $1,092 \pm 151$ & \\
CCK-8-NS & 400 & 7 & $902 \pm 144$ & N.S. vs. saline \\
& 800 & 11 & $1,440 \pm 309$ & N.S. \\
& 1,600 & 13 & $1,662 \pm 205$ & $P<0.05$ \\
Saline & & 17 & $1,220 \pm 82$ & \\
Caerulein & 50 & 11 & $1,268 \pm 185$ & N.S. $v s$. saline \\
& 100 & 11 & $1,278 \pm 183$ & N.S. \\
& 200 & 8 & $969 \pm 222$ & N.S. \\
& 400 & 8 & $1,290 \pm 227$ & N.S. \\
& 800 & 11 & $1,025 \pm 104$ & N.S. \\
& 1,600 & 10 & $1,159 \pm 115$ & N.S. \\
\hline
\end{tabular}

Each material was injected in a volume of $5 \mu 1$. N.S.: not significant. 
Table 5. Body shaking response induced by TRH.

\begin{tabular}{lrccl}
\hline Treatment & $\begin{array}{c}\text { Dose } \\
\text { (ng) }\end{array}$ & $\begin{array}{c}\text { No. of } \\
\text { rats }\end{array}$ & $\begin{array}{c}\text { No. of shakes } \\
\text { Counts/hr } \\
\text { (mean } \pm \text { S.E.M.) }\end{array}$ & \multicolumn{1}{c}{$t$-Test } \\
\hline Saline & 1 & 5 & $0 \pm 0.2$ & \\
TRH & 5 & 5 & $6 \pm 0.4$ & N.S. vs. saline \\
& 25 & 5 & $10 \pm 2.5$ & $P<0.01$ \\
& 100 & 5 & $22 \pm 3.5$ & $P<0.001$ \\
& 400 & 5 & $55 \pm 5.4$ & $P<0.001$ \\
& 1,600 & 5 & $76 \pm 6.6$ & $P<0.001$ \\
CCK-8 & 100 & 5 & $105 \pm 11.8$ & $P<0.001$ \\
& 400 & 5 & $0 \pm 0.2$ & N.S. vs. saline \\
& 1,600 & 5 & $0 \pm 0.2$ & N.S. \\
TRH & 400 & & $4 \pm 0.2$ & N.S. \\
$\quad+$ & 1,600 & 9 & $86 \pm 4.4$ & N.S. vs. TRH alone \\
CCK-8 & 1,600 & & & \\
TRH & 1,600 & 5 & $114 \pm 8.7$ & N.S. \\
$\quad$ CCK-8 & & & & \\
\hline
\end{tabular}

Each material was injected in a volume of $10 \mu 1$. N.S.: not significant.

\section{Body shaking response}

The i.c.v. injection of TRH in small doses of even $5 \mathrm{ng}$ caused a peculiar body shaking response, the number of shakes being dose-dependent (Table 5). CCK-8 did not produce such symptoms and the TRH-induced shaking response was not affected by combined administration of CCK-8.

\section{DISCUSSION}

TRH has been reported to shorten the sleeping time induced by barbiturates and other depressants, as mentioned before. In pentobarbital-narcotized rabbits, intracerebral injection of TRH was also shown to exert analeptic activity regardless of the brain area injected (CARINo et al., 1976). On the other hand, ZETLER (1980c) found that s.c. injection of caerulein and CCK-8 into mice produced sedation, palpebral ptosis and analgesia. The injection of these peptides inhibited spontaneous rearing activity and prolonged hexobarbital-induced sleeping time (ZETLER, 1980b). Accordingly, CCK-8 is assumed to be antagonistic to the central action of TRH. In fact, the present study demonstrated that the duration of pentobarbital- and ethanol-induced narcosis was prolonged by CCK-8 and shortened by TRH, and that these effects were reduced when these two peptides were administered simultaneously.

Costall et al. (1979) reported that intraventricular or intracerebral injection of TRH into rats induced a variety of motor effects, such as shakes, limb tremor, repetitive head and limb movements, biting, scratching, and an alertness. Ac- 
cording to CARINO et al. (1976), behavioral excitation was most pronounced after administration of TRH into the cerebral cortex, caudate nucleus, and hypothalamus. However, MASSERANO and KING (1981) have shown that locomotor activity increases after injection of TRH into the hypothalamus, but not into the caudate nucleus and septum. TRH receptor binding is likely to vary markedly in the brain regions. OGAwA et al. (1981) reported that the limbic system contained the greatest amount of binding sites, the next highest areas being the cerebral cortex, hypothalamus, interpeduncular nucleus, and periaquaductal gray matter of the midbrain. Thus, the sites of action of TRH are not simply determined.

Regarding the mode of action of TRH, an increase in the brain catecholamine turnover has been reported by a number of investigators, and the presynaptic dopamine release was suggested to be stimulated by TRH (REIGLE et al., 1974; Horst and SpIRT, 1974; Kerwin and PyCOCK, 1979). GreEN et al. (1976) assumed that TRH modulates dopamine-mediated behavioral responses by a presynaptic mechanism of action, possibly by releasing dopamine. Furthermore, it was inferred that, of the two major dopamine terminal areas in the rat brain, the mesolimbic nucleus accumbens rather than the extrapyramidal nucleus caudatus is the site where TRH selectively modulates presynaptic dopaminergic mechanisms (HEAL and GreEN, 1979). In marked contrast to TRH, CCK-8 is likely to inhibit the release of dopamine in the presynaptic nerve endings (FUXE et al., 1980). In this line of literature, it would be presumed that the antagonistic action of CCK-8 on TRH-induced excitation may be due to its inhibitory effect on dopamine release from the presynaptic nerve endings, particularly in the mesolimbic nucleus.

However, there might be different sites of action and mechanisms for CCK-8 and TRH. Thus, their effects may not always oppose each other. CCK-binding sites in the rat brain are correlated to its cerebral distribution (SAITo et al., 1980) and they are not in accord with those for TRH. Accordingly, some effects of TRH, such as body shaking, are not antagonized by CCK-8. WEI (1981) demonstrated that injection of TRH into medial brainstem areas produced vigorous shaking, while injection into the lateral regions of the brain was relatively inactive. The body shaking-inducing areas are different from the brain regions containing massive amounts of CCK.

Stimulant properties of amphetamine are similar to those of TRH in various respects (MANBERG et al., 1979). In the present experiments, hyperactivity induced by methamphetamine was effectively suppressed by CCK-8, as seen in the case of TRH. The observation apparently indicates a sedative action of CCK8. One of the interesting findings in this study is that caerulein is ineffective in suppressing methamphetamine-induced hyperactivity. Moreover, CCK-8-NS itself produced an enhanced locomotor activity and it caused an enhancement of hyperactivity induced by methamphetamine when injected in relatively large 
amounts. Since commercial caerulein preparations do not correspond to the label claim (De Castiglione and Di SAlle, 1980), reasonable conclusions could not be drawn as to the effect of caerulein. However, the fact that CCK-8 had a sedative action, while CCK-8-NS enhanced locomotor activity suggests that the presence of the sulfate group on the tyrosine residue is indispensable for the exertion of the action of CCK in the inhibition of presynaptic dopamine release.

CCK-8 used in the present study was generously donated by Mr. S. J. Lucania, the Squibb Institute for Medical Research. The skillful technical assistance of Mrs. Y. Maeda is gratefully acknowledged.

\section{REFERENCES}

Breese, G. R., Cott, J. M., Cooper, B. H., Prange, A. J., Jr., Lipton, M. A., and Plotnikoff, N. P. (1975) Effects of thyrotropin-releasing hormone (TRH) on the actions of pentobarbital and other centrally acting drugs. J. Pharmacol. Exp. Ther., 193: 11-22.

Brown, M. and VALe, W. (1975) Central nervous system effects of hypothalamic peptides. Endocrinology, 96: 1333-1336.

Carino, M. A., Smith, J. R., Weick, B. B., and Horita, A. (1976) Effects of thyrotropinreleasing hormone (TRH) microinjected into various brain areas of conscious and pentobarbital-pretreated rabbits. Life Sci., 19: 1687-1692.

Costall, B., Hui, S. C. G., Metcalf, G., and Naylor, R. J. (1979) A study of the changes in motor behavior caused by TRH on intracerebral injection. Eur. J. Pharmacol., 53: 143-150.

Cott, J. M., Breese, G. R., Cooper, B. R., Barlow, T. S., and Prange, A. J., Jr. (1976) Investigations of ethanol sleep by thyrotropin-releasing hormone (TRH). J. Pharmacol. Exp. Ther., 196: 594-604.

De Castiglione, R. and Di Salle, E. (1980) Is commercial "cerulein" always true cerulein? Gastroenterology, 78: 1113-1114.

Fuxe, K., Andersson, K., Locatelli, V., Agnati, L. F., Hökfelt, T., Skirboll, L., and Mutt, V. (1980) Cholecystokinin peptides produce marked reduction of dopamine turnover in discrete areas in the rat brain following intraventricular injection. Eur. J. Pharmacol., 67: 329-331.

Green, A. R., Heal, D. J., Grahame-Smith, D. G., and Kelly, P. H. (1976) The contrasting actions of TRH and cycloheximide in altering the effects of centrally acting drugs. Neuropharmacology, 17: 265-270.

Heal, D. J. and Green, A. R. (1979) Administration of thyrotropin-releasing hormone (TRH) to rats releases dopamine in n. accumbens but not in n. caudatus. Neuropharmacology, 18: $23-31$.

Horst, W. D. and SPIRT, N. (1974) A possible mechanism for the antidepressant activity of thyrotropin-releasing hormone. Life Sci., 15: 1073-1082.

Itoh, S., Hirota, R., Katsuura, G., and Odaguchi, K. (1979) Adrenocortical stimulation by a cholecystokinin preparation in the rat. Life Sci., 25: 1725-1730.

Kerwin, R. W. and Pycock, C. J. (1979) Thyrotropin releasing hormone stimulates release of ${ }^{3} \mathrm{H}$-dopamine from slices of rat nucleus accumbens in vitro. Br. J. Pharmacol., 67: 323-325.

Manberg, P. J., Nemeroff, C. B., and Prange, A. J., Jr. (1979) Thyrotropin-releasing hormone: A comparison of pharmacological profiles in animals. Prog. Neuro-Psychopharmacol., 3: 303-314.

MASSERANO, J. M. and KING, C. (1981) TRH increases locomotor activity in rats after injec- 
tion into the hypothalamus. Eur. J. Pharmacol., 69: 217-219.

Ogawa, N., Yamawaki, Y., Kuroda, H., Ofuji, T., Itoga, E., and Kito, S. (1981) Discrete regional distribution of thyrotropin releasing hormone (TRH) receptor binding in monkey central nervous system. Brain Res., 205: 169-174.

Plotnikoff, N. P., Prange, A. J., Jr., Breese, G. R., Anderson, M. S., and Wilson, I. C. (1972) Thyrotropin releasing hormone: Enhancement of dopa activity by a hypothalamic hormone. Science, 178: 417-418.

Plotnikoff, N. P., Prange, A. J., Jr., Breese, G. R., and Wilson, I. C. (1974) Thyrotropin releasing hormone: Enhancement of dopa activity in thyroidectomized rats. Life Sci., 14: 1271-1278.

Reigle, T. G., Avni, J., Platz, P. A., Schildkraut, J. J., and Plotnikoff, N. P. (1974) Norepinephrine metabolism in the rat brain following acute and chronic administration of thyrotropin-releasing hormone. Psychopharmacologia, 37: 1-6.

Saito, A., Sankaran, H., Goldfine, I. D., and Williams, J. A. (1980) Cholecystokinin receptors in the brain: Characterization and distribution. Science, 208: 1155-1156.

WEI, E. T. (1981) Pharmacological aspects of shaking behavior produced by TRH, AG-3-5, and morphin withdrawal. Fed. Proc., 40: 1491-1496.

ZETLER, G. (1980a) Anticonvulsant effects of caerulein and cholecystokinin octapeptide, compared with those of diazepam. Eur. J. Pharmacol., 65: 297-300.

ZetLeR, G. (1980b) Effects of cholecystokinin-like peptides on rearing activity and hexobarbital-induced sleep. Eur. J. Pharmacol., 66: 137-139.

ZETLER, G. (1980c) Analgesia and ptosis caused by caerulein and cholecystokinin octapeptide (CCK-8). Neuropharmacology, 19: 415-422. 